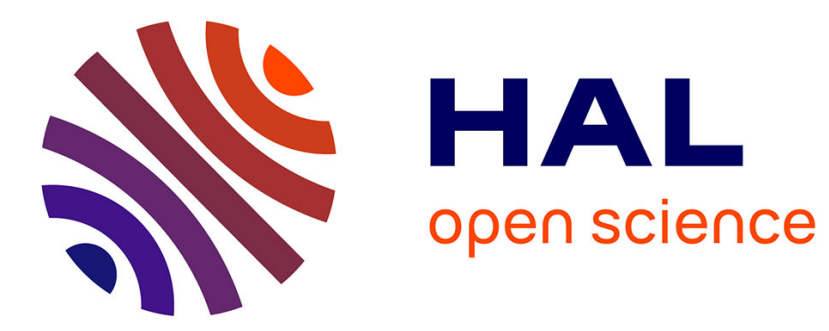

\title{
Evidence that release of internal stress contributes to drying strains of wood \\ Bruno Clair
}

\section{To cite this version:}

Bruno Clair. Evidence that release of internal stress contributes to drying strains of wood. Holzforschung, 2012, 66 (3), pp.349-353. 10.1515/HF.2011.159 . hal-00641282

\section{HAL Id: hal-00641282 \\ https://hal.science/hal-00641282}

Submitted on 15 Nov 2011

HAL is a multi-disciplinary open access archive for the deposit and dissemination of scientific research documents, whether they are published or not. The documents may come from teaching and research institutions in France or abroad, or from public or private research centers.
L'archive ouverte pluridisciplinaire HAL, est destinée au dépôt et à la diffusion de documents scientifiques de niveau recherche, publiés ou non, émanant des établissements d'enseignement et de recherche français ou étrangers, des laboratoires publics ou privés. 


\title{
Short title: Stress release during drying
}

\section{Evidence that release of internal stress contributes to drying strains of wood}

\author{
Bruno CLAIR \\ Laboratoire de Mécanique et de Génie Civil (LMGC) \\ Université Montpellier 2, CNRS \\ CC48, Place E. Bataillon, 34095 Montpellier, France \\ bruno.clair@univ-montp2.fr
}

\begin{abstract}
Wood shrinks during drying with the departure of bond water. Along the fibre direction, the magnitude of this shrinkage is mainly governed by the orientation of cellulose microfibrils (MF) in the cell wall. However, tension wood has an unexpectedly high longitudinal shrinkage considering the fact that MFs are oriented nearly parallel to the cell direction. This effect is thought to be due to the gel collapse of G-layer, however, some species producing a tension wood without G-layer also exhibit a higher longitudinal shrinkage than normal wood. The aim of this study is to analyse the contribution of maturation stresses to drying shrinkage.

Longitudinal and tangential drying shrinkage of tension wood and normal wood were measured on two sets of matched chestnut wood samples. The first set was directly ovendried, whereas on the second set a hygrothermal treatment released the maturation stress before oven-drying. The analysis of the strains during each step of the procedure reveals that part of the drying shrinkage is due to the release of internal stresses during the desorption process. Finally, a tentative schematic model is proposed taking into account the cumulative contributions to longitudinal drying shrinkage.
\end{abstract}

Keywords: hygrothermal recovery; maturation stresses; shrinkage; tension wood; wood drying 


\section{Introduction}

It is still a challenge to reduce the high water content of wood in living trees to the level needed for wood utilization and to avoid shrinkage associated damages during drying.

The magnitude of wood shrinkage is highly anisotropic. Typically for a temperate hardwood, it amounts $0.1-0.2 \%$ along the fibre axis $(\mathrm{L}), 3-5 \%$ in the radial (R) direction, and $6-10 \%$ in the tangential $(\mathrm{T})$ direction. In the transverse plane, the magnitude of the shrinkage is highly affected by the cellular structure, while in L direction, shrinkage is mainly governed by the cell wall organisation. Barber and Meylan (1964) proposed a model, which was refined by Barber (1968), simplifying the cell wall to its S2 layer.

Later, more sophisticated models were proposed integrating other properties, changes in matrix behaviour during drying, and considering the different cell wall layers (Barrett et al. 1972; Cave 1972a, 1972b, 1978; Gril et al. 1999; Yamamoto 1999; Yamamoto et al. 2005). In these models, the sites of water sorption-desorption are located in a hygroscopic matrix. As known, this matrix is reinforced by the stiff cellulose microfibrils (MF), which restrain hygroexpansion in the direction parallel to their axes. Thus, microfibril angle (MFA) is the determinant factor of L shrinkage. A low MFA induces low L shrinkage and a high MFA has the opposite effect. This relation is clearly observed in juvenile wood (JW) or compression wood (CW) where MFA is very large.

But these models cannot explain the behaviour of tension wood (TW), in which MFA is always very low (Ruelle et al. 2006), while macroscopic L shrinkage is always higher than in normal wood (NW) (Clarke 1937; Chow 1946; Clair et al. 2003a; Clair et al. 2003b; Washusen et al. 2003; Yamamoto et al. 2010; Ruelle et al. 2011). The L shrinkage is especially high (up to 10 times higher than in NW) in species, in which TW is associated to the production of the so called G-layer. It was shown that in these species the shrinkage is due to the mesoporous texture of the G-layer and its collapse during drying (Clair et al. 2008). However, there are species without G-layer in their TW, and the L shrinkage is still twice as high than in NW (Ruelle et al. 2011). This behaviour is difficult to interpret.

A recent study on the behaviour of wood during ethanol exchange shows that nonnegligible residual strain occurs during the sorption-desorption process (Chang et al. 2009). These strains, observed both on chestnut (a species producing G-layer) and simarouba (forming TW without G-layer), were attributed to stress release in the sample owing to the molecular mobility operating as a softener of the cell wall. Observations of Abe and Yamamoto (2007) also substantiated the suspicion that stress release occurs during drying. The quoted authors studied the effect of boiling tension of wood during drying and demonstrated that L shrinkage is lower after boiling, as compared to unboiled samples.

The background of the present work was the hypothesis that a part of the strain occurring during drying is linked to the release of auto-stress accumulated in the sample during wood formation (maturation stress). Drying shrinkage of a (auto-stressed) native sample should be studied after being released from maturation stresses. A well established way to release stress in wood is hygrothermal treatment at around $80^{\circ} \mathrm{C}$ under wet conditions (Kübler 1987; Chafe 1992; Gril and Thibaut 1994; Jullien and Gril 1996). This treatment, also used in industrial process as steaming, is called hygrothermal recovery (HTR) as it allows to recover locked-in strains resulting from maturation stresses (Kübler 1987). It is done under water and the collapse of the gel in TW is avoided; strain occurring during treatment can only be attributed to stress release.

Thus, in the present work drying shrinkage of NW and TW of chestnut was measured on two sets of matched samples. The first set was directly oven-dried whereas on the second set oven-drying was preceded by a bath in hot water $\left(80^{\circ} \mathrm{C}\right)$ during one hour. A comparison of the two sets allows to identify the amount of strain in native auto-stressed and in non-stressed 
samples. The expectation was to obtain information on the contribution of locked strain recovery on total strain measured during drying.

\section{Material and methods}

Experiments were performed on 10 samples of NW and 10 of TW taken from a tilted chestnut tree (Castanea sativa Mill.) in which TW was characterized by a large amount of thick Glayer and high mesoporosity (Clair et al 2008). After falling the tree, wood was stored as log in a room at $5^{\circ} \mathrm{C}$ during several months with special care to avoid any drying. Samples were kept green (never dried) at the beginning of experiments. Sample size was $2 \times 10 \times 60 \mathrm{~mm}^{3}$ $(\mathrm{R}, \mathrm{T}$, and $\mathrm{L})$.

Samples were divided in two paired sets A and B. Samples from set A were directly oven-dried at $102^{\circ} \mathrm{C}$. Set B samples were subject to hygrothermal (HT) treatment by heating in water during $1 \mathrm{~h}$ at $80^{\circ} \mathrm{C}$ and slowly cooled down. Then the samples were oven-dried at $102^{\circ} \mathrm{C}$.

Sample dimensions were measured in $\mathrm{L}$ and $\mathrm{T}$ directions with a digital micrometer (0.001 mm precision) first under never-dried conditions (sets A and B), then after heating and cooling down (only set B), then after oven-drying (sets A and B). Macroscopic strains are defined as follows:

For set A and B, total strain: $\varepsilon_{\text {tot }}=\left(D_{\text {Oven-dry }}-D_{\text {green }}\right) / D_{\text {green }}$

For set B only, HT strain: $\varepsilon_{H T}=\left(D_{H T}-D_{\text {green }}\right) / D_{\text {green }}$

Pure drying strain: $\varepsilon_{P D}=\varepsilon_{\text {tot }}-\varepsilon_{H T}$ where $D_{\text {green }}, D_{\text {Oven-dry }}, D_{H T}$ are the dimension ( $\mathrm{L}$ or T) in green state, after oven drying and after hygrothermal treatement, respectively. On each sample, the microfibril angle (MFA) was measured by X-ray diffraction with a 4-circle diffractometer (Oxford Diffraction Gemini S) equipped with a $1024 \times 1024 \mathrm{CCD}$ camera. $\mathrm{CuK} \alpha$, radiation was generated by an X-ray generator operating at $50 \mathrm{kV}, 25 \mathrm{~mA}$. Images were integrated between $2 \theta=21.5^{\circ}$ and $23.5^{\circ}$ along the whole $360^{\circ}$ azimuthal interval to plot the intensity diagram of the (200) plane. An automatic procedure allowed the detection of the 200 peaks and their inflexion points. The $\mathrm{T}$ parameter as defined by Cave (1966) was measured as the half distance between intersections of tangents at inflexion points with the baseline. The average MFA of each specimen was estimated by the "improved Cave's method" (Yamamoto et al. 1993). The results are given as the mean of values obtained for the two (200) peaks.

\section{Results}

Figure 1 presents the data of all strain measurements performed in this study and Table 1 gives the value of the mean strain and the corresponding confidence interval (at $95 \%$ ). The Lstrain results for the HT treatment showed that NW swelled slightly $\left(\varepsilon_{\mathrm{HT}}=0.04 \%\right)$ while TW shrunk significantly more $\left(\varepsilon_{\mathrm{HT}}=-0.14 \%\right)$; for the T-direction both NW and TW swelled but the TW swelled more than 3 times more.

During the pure drying phase, TW shrunk slightly more than NW along T direction, and in L direction shrinkage was 3 times higher in TW compared to NW. The total drying strain is not statistically different between the sets A and B with approximately $0.7-0.8 \% \mathrm{~L}$ shrinkage in TW compared to $0.1-0.2 \%$ in NW and 5-6 \% T shrinkage both in NW and TW. This implies that the total strain is not affected by the HT treatment neither in NW nor in TW.

Fig. 1

Table 1

Figure 2 presents the microfibrils angle (MFA) of each sample and the corresponding strains. These measurements confirmed the low MFA in TW compared to NW and showed the large 
range of MFA in TW compared to NW, which is more homogeneous in MFA. Finally, the similar repartition of MFA values in samples from both sets confirmed the good quality of the matching. Considering all samples of a given set, the high contrast between NW and TW made the relationship between strains and MFA always highly significant. For HTR strains along L, the tendency was a slight swelling for large MFA and a shrinkage for low MFA, whereas along $\mathrm{T}$ the swelling increased with decreasing MFA. For drying strains $\left(\varepsilon^{B}{ }_{P D}, \varepsilon_{\text {tot }}^{A}\right.$ and $\varepsilon^{B}$ tot) the statement is valid: the lower the MFA, the higher the shrinkage both along $\mathrm{T}$ and L directions. Maximum L strains appeared when MFA was the lowest, i.e. when amount of G-layer was the highest.

Fig. 2

\section{Discussion}

HTR strain data confirmed the few data available with this regard: T swelling is higher in TW compared to NW (Gril et al. 1993). For L direction, no literature data were found.

It is a clear difference between the behaviour of NW and TW in pure L shrinkage

$\left(\varepsilon^{B}{ }_{P D}\right)$ which is also visible in total strain $\left(\varepsilon_{\text {tot }}^{A}\right.$ and $\left.\varepsilon_{\text {tot }}^{B}\right)$. This distinct difference indicates that a continuum does not exists concerning the mechanism of pure drying shrinkage from NW to TW. This can be explained by the presence of G-layer in TW, in which drying produces gel collapse inducing very large $L$ macroscopic shrinkage (Clair et al. 2008). In the T direction, as reported by Fang (2007), the effect of gel collapse only slightly affects the transverse shrinkage because of the combination of a low transverse stiffness of the G-layer and the absence of restricting $\mathrm{S}_{3}$ layer.

No significant differences are recorded in the total shrinkage of the two sets of samples $\left(\varepsilon_{\text {tot }}^{A}\right.$ et $\left.\varepsilon_{\text {tot }}^{B}\right)$ proving that HT treatment does not produce additional strain nor restrains the deformation of the sample. Accordingly, part of the total drying strain is due to a strain that can be released by HT treatment. This was previously suspected from a study on the effect of boiling on tension wood showing that L drying shrinkage is less after boiling compared to unboiled samples (Abe and Yamamoto 2007).

Then the strain which is occurring during drying could be considered as the superposition of 3 effects at the cell wall level:

1. The effect of the space-loss occupied by water. This effect is the best described one in the literature and is generally considered as the only effect allowing shrinkage at the cell wall level. The larger the MFA, the higher is the axial shrinkage and the lower the transverse shrinkage of the wall. This has been largely verified experimentally and by modelling. On our data set, this can also be clearly observed in T direction. Along $\mathrm{L}$ direction, despite the narrow range of MFA in NW the relationship is significant $\left(\mathrm{r}^{2}=0.17, \mathrm{n}=10\right)$ among NW samples. In TW, the relationship is hidden by the gel collapse effect.

2. The effect of strain recovery, which is visible mainly in highly prestressed wood (tension wood), but which is not negligible in NW either. This effect implies that something occurs during normal drying that allows stress release like during HTR. Several factors could contribute to the stress release. First, during the first phase of the drying, the high moisture content (MC) associated with temperature above $80^{\circ} \mathrm{C}$ creates conditions of hygrothermal recovery. Additionally, the desorption process occurring during drying acts to destabilise macromolecules and produce a softening of the wood material. This phenomenon, known as "mecanosorption", is explained by the molecular mobility during sorption/desorption processes (Armstrong and Kingston 1960; Hunt 1986). Similarly, exchange from water to alcohol allows the release of internal stress in TW samples (Chang et al. 2009). In this later study, authors show that the stress release does not depend on the presence of G-layer. 
3. The effect of gel collapse, dominating over the previous effects but occurring only in G-layer tension wood (Clair et al. 2008). This effect produces a rupture in behaviour from NW to TW and can occur only in species producing G-layer.

A tentative schematic model of $\mathrm{L}$ shrinkage is proposed in Figure 3. An equivalent simple model is not possible in $\mathrm{T}$ direction due to the difficultly to take into account structural effects at the level of cell organisation and because the transverse behaviour of G-layer is not yet generalized. Figure 3 illustrates the cumulative contribution of the 3 effects discussed above as a function of the maturation strain than can be measured in the standing tree. In this model, water departure strain depends on MFA. MFA is supposed to decrease from CW (positive maturation strain) to NW. In TW, MFA is close to zero and then prevents most of this source of L shrinkage. The water departure shrinkage was computed with a shrinkage perpendicular and parallel to the microfibrils at $3 \%$ and $0 \%$, respectively, and with MFA varying from $35^{\circ}$ in $\mathrm{CW}$ (maturation strain $=300 \mu \varepsilon$ ) to 0 in $\mathrm{TW}$ (maturation strain $=-900$ to $-2000 \mu \varepsilon$ ). The released strain was supposed to be equal to maturation strain (e.g. $0.1 \%$ when $-1000 \mu$ strain). This makes the model more transparent but would insinuate that NW studied in this work is a CW because a positive HTR strain was recorded in NW. Finally, the strain due to the gel collapse just depends on the amount of gel in the wood sample. Several studies show that this amount is positively related to maturation strain in species producing G-layers (the higher the G-layer content, the higher the tensile strain) (Clair et al. 2003b; Fang et al. 2008; Yamamoto et al. 2010). The model is computed with a linear increase of shrinkage from 0 when no G-layer $(-800 \mu \varepsilon)$ to $1 \%$, when the sample is full of G-layer in strong tension wood $(-2000 \mu \varepsilon)$.

This simple model illustrates the components of the shrinkage. Thus, it predicts that TW without G-layer can have a higher L shrinkage than NW but always much smaller than in TW containing G-layer. This has been verified by Ruelle et al. (2007a) by comparing properties of ten tropical species; it was reported that "L shrinkage was often the most significantly different property between tension and opposite wood, 4 to 7 times higher in tension wood for 7 species, but less than 2 times higher for Simarouba amara Aubl., Eschweilera decolorens Sandw. and Qualea rosea". Two of these genera (Simarouba and Eschweilera) are known to produce TW without a G-layer (Clair et al. 2006; Ruelle et al. 2007b). This L shrinkage is much less than in TW with a G-layer but the finding is still paradox in view of the lower MFA in comparison to NW, as predicted by the model. Within a more detailed study on simarouba TW, Ruelle (2011) shows that the increment of shrinkage from NW to TW ranged from 0.1 to $0.2 \%$, which is in the same order of magnitude than the HTR strain recorded in this study and give support to the proposed model. It would be interesting, however, to validate this hypothesis by performing similar experiment on sample from a species without G-layer.

\section{Fig. 3}

\section{Conclusion}

Experiments performed on chestnut wood show that the strain recovery obtained by the released of maturation stresses during heat treatment contributes to the total strain observed during drying. This contribution is not only visible in tension wood but also in normal wood; both in the longitudinal ant tangential direction.

Some more observations by X-ray diffraction are now planned to follow the cellulose strains during several phases of the shrinkage to understand better the mechanisms at the macromolecular level. 


\section{Acknowledgements}

Many thanks are due to the members of the team Tree and wood mechanics at LMGC for valuable discussions and especially, to P. Cabrolier for providing wood sample and to T. Alméras, J. Gril and B. Thibaut for their critical reading of the manuscript.

\section{References}

Abe, K., Yamamoto, H. (2007) The influences of boiling and drying treatments on the behaviors of tension wood with gelatinous layers in Zelkova serrata. Int. J. Wood Sci. 53(1):5-10.

Armstrong, L.D., Kingston, R.S.T. (1960) Effect of moisture changes on creep in wood. Nature 185(4716):862-863.

Barber, N.F. (1968) A Theoretical Model of Shrinking Wood. Holzforschung 22(4):97-103

Barber, N.F., Meylan, B.A. (1964) The anisotropic shrinkage of wood. Holzforschung 18(5):146-156.

Barrett, J.D., Schniewind, A.P., Taylor, R.L. (1972) Theoretical Shrinkage Model for Wood Cell Wall. Wood Sci. 4:178-192.

Cave, I.D. (1966) Theory of X-ray measurement of microfibril angle in wood. Forest Prod. J. 16(10):37-42.

Cave, I.D. (1972a) Swelling of a fibre reinforced composite in which the matrix is water reactive. Wood Sci. Technol. 6:157-161.

Cave, I.D. (1972b) A Theory of the Shrinkage of Wood. Wood Sci. Techn. 6:284-292

Cave, I.D. (1978) Modelling Moisture-Related Mechanical Properties of Wood. Part I: Properties of the Wood Constituents. Wood Sci. Technol. 12:75-86.

Chafe, S.C. (1992) The Effect of Boiling Time on the Change in Green Wood Volume in Eucalyptus regnans F. Muell. Holzforschung 46(6):463-466.

Chang, S.S., Clair, B., Gril, J., Yamamoto, H., Quignard, F. (2009) Deformation induced by ethanol substitution in normal and tension wood of chestnut (Castanea sativa Mill.) and simarouba (Simarouba amara Aubl.). Wood Science and Technol. 43(7):703 - 71.2

Chow, K.Y. (1946) A comparative study of the structure and chemical composition of tension wood and normal wood in beech (Fagus sylvatica L.). Forestry 20:62-78.

Clair, B., Gril, J., Di Renzo, F., Yamamoto, H., Quignard, F. (2008) Characterization of a gel in the cell wall to elucidate the paradoxical shrinkage of tension wood.

Biomacromolecules 9:494-498.

Clair, B., Jaouen, G., Beauchêne, J., Fournier, M. (2003a) Mapping radial, tangential and longitudinal shrinkages and relation to tension wood in discs of the tropical tree Symphonia globulifera. Holzforschung 57(6):665-671.

Clair, B., Ruelle, J., Beauchêne, J., Prévost, M.-F., Fournier Djimbi, M. (2006) Tension wood and opposite wood in 21 tropical rain forest species. 1. Occurrence and efficiency of the G-layer. IAWA Journal 27(3):329-338.

Clair, B., Ruelle, J., Thibaut, B. (2003b) Relationship between growth stress, mechanophysical properties and proportion of fibre with gelatinous layer in Chestnut (Castanea sativa Mill.). Holzforschung 57(2):189-195.

Clarke, S.H. (1937) The distribution, structure and properties of tension wood in Beech (Fagus silvatica L.). Forestry 11(2):85-91.

Fang, C.-H., Clair, B., Gril, J., Alméras, T. (2007) Transverse shrinkage in G-fibers as a function of cell wall layering and growth strain. Wood Sci. Technol. 41(8):659-671

Fang, C.-H., Clair, B., Gril, J., Liu, S.-Q. (2008) Growth stresses are highly controlled by the amount of G-layer in poplar tension wood. IAWA J. 9(3):237-246. 
Gril, J., Berrada, E., Thibaut, B. (1993) Recouvrance hygrothermique du bois vert. Il. Variations dans le plan transverse chez le châtaignier et l'épicéa et modélisation de la fissuration à coeur provoquée par l'étuvage. Ann. Sci. For. 50:487-508.

Gril, J., Sassus, F., Yamamoto, H., Guitard, D. (1999) Maturation and drying strain of wood in longitudinal direction: a single-fibre mechanical model. 3rd Workshop on Connection between silviculture and wood quality through modelling approaches and simulation softwares (IUFRO WP S5.01.04 "Biological Improvement of Wood Properties"). Ed. Nepveu, G. La Londe-Les-Maures. ERQB-INRA Nancy. pp. 309-313.

Gril, J., Thibaut, B. (1994) Tree mechanics and wood mechanics: relating hygrothermal recovery of green wood to the maturation process. Ann. Sci. For. 51:329-338.

Hunt, D.G. (1986) The mechano-sorptive creep susceptibility of two softwoods and its relation to some other materials properties. J. Mat. Sci. 21(6):2088-2096.

Jullien, D., Gril, J. (1996) Mesure des déformations bloquées dans un disque de bois vert. Méthode de la fermeture. Ann. Sci. For. 53(5):955-966.

Kübler, H. (1987) Growth stresses in trees and related wood properties. Forest Prod. Abstr. 10(3):62-119.

Ruelle, J., Beauchêne, J., Thibaut, A., Thibaut, B. (2007a) Comparison of physical and mechanical properties of tension and opposite wood from ten tropical rainforest trees from different species. Ann. For. Sci. 64(5):503-510.

Ruelle, J., Beauchêne, J., Yamamoto, H., Thibaut, B. (2011) Variations in physical and mechanical properties between tension and opposite wood from three tropical rainforest species. Wood Sci. Technol. 45(339-357).

Ruelle, J., Clair, B., Beauchêne, J., Prévost, M.-F., Fournier, M. (2006) Tension wood and opposite wood in 21 tropical rain forest species. 2. Comparison of some anatomical and ultrastructural criteria. IAWA J. 27(4):341-376.

Ruelle, J., Yamamoto, H., Thibaut, B. (2007b) Growth stresses and cellulose structural parameters in tension and normal wood from three tropical rainforest angiosperm species. BioResources 2(2):235-251.

Washusen, R., Ilic, J., Waugh, G. (2003) The relationship between longitudinal growth strain, tree form and tension wood at the stem periphery of ten- to eleven-year-old Eucalyptus globulus Labill. Holzforschung 57(3):308-316.

Yamamoto, H. (1999) A model of anisotropic swelling and shrinking process of wood. Part 1. Generalization of Barber's wood fiber model. Wood Sci. Technol. 33:311-325.

Yamamoto, H., Abe, K., Arakawa, Y., Okuyama, T., Gril, J. (2005) Role of the gelatinous layer (G-layer) on the origin of the physical properties of the tension wood of Acer sieboldianum. J. Wood Sci. 51(3):222-233.

Yamamoto, H., Okuyama, T., Yoshida, M. (1993) Method of determining the mean microfibril angle of wood over a wide range by the imporved cave's method. Mokuzai Gakkaishi 39(4):375-381.

Yamamoto, H., Ruelle, J., Arakawa, Y., Yoshida, M., Clair, B., Gril, J. (2010) Origin of the characteristic hygro-mechanical properties of the gelatinous layer in tension wood from Kunugi oak (Quercus acutissima). Wood Sci. Technol. 44(1):149-163. 
Table 1: Mean strain and confidence interval at 95\% $\left(\mathrm{MEAN}^{ \pm \mathrm{CI}}\right)$ for each step of the experiment on normal wood (NW) and tension wood (TW). L: longitudinal direction; T: tangential direction; A and B index refer to the name of the set.: $\varepsilon_{\text {tot }}$ : total strain , $\varepsilon_{H T}$ : HT strain, $\varepsilon_{P D}$ : pure drying strain.

\begin{tabular}{ccccc}
\hline $\mathrm{L}$ & $\varepsilon^{\mathrm{LA}}{ }_{\text {tot }}(\%)$ & $\varepsilon^{\mathrm{LB}}{ }_{\mathrm{HT}}(\%)$ & $\varepsilon^{\mathrm{LB}}{ }_{\mathrm{PD}}(\%)$ & $\varepsilon^{\mathrm{LB}}{ }_{\text {tot }}(\%)$ \\
TW & $-0.76^{ \pm 0.08}$ & $-0.14^{ \pm 0.05}$ & $-0.64^{ \pm 0.05}$ & $-0.78^{ \pm 0.08}$ \\
$\mathrm{NW}$ & $-0.13^{ \pm 0.05}$ & $0.04^{ \pm 0.02}$ & $-0.20^{ \pm 0.03}$ & $-0.16^{ \pm 0.04}$ \\
\hline $\mathrm{T}$ & $\varepsilon^{\mathrm{TA}}{ }_{\text {tot }}(\%)$ & $\varepsilon^{\mathrm{TB}}{ }_{\mathrm{HT}}(\%)$ & $\varepsilon^{\mathrm{TB}}{ }_{\mathrm{PD}}(\%)$ & $\varepsilon^{\mathrm{TB}}{ }_{\text {tot }}(\%)$ \\
TW & $-5.53^{ \pm 0.82}$ & $0.58^{ \pm 0.26}$ & $-6.64^{ \pm 0.53}$ & $-6.06^{ \pm 0.38}$ \\
$\mathrm{NW}$ & $-5.03^{ \pm 0.62}$ & $0.15^{ \pm 0.15}$ & $-5.37^{ \pm 0.66}$ & $-5.22^{ \pm 0.55}$ \\
\hline
\end{tabular}

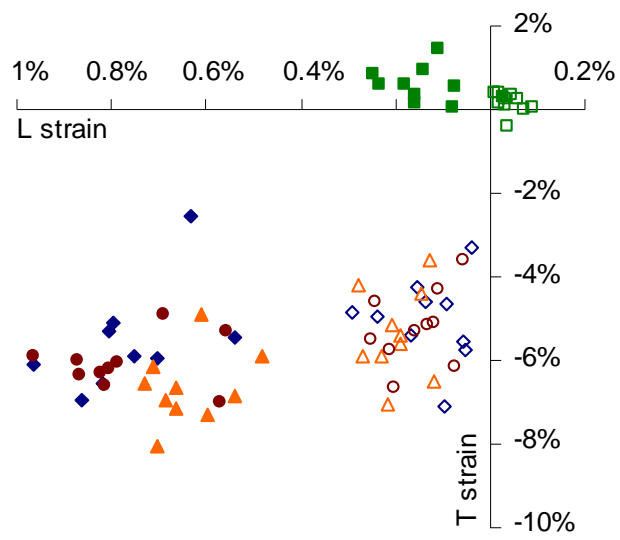

Fig. 1: Longitudinal (L) versus tangential (T) strains measured on normal wood (open symbols) and tension wood (filled symbols). Square $=$ HT strain on set B $\left(\varepsilon^{B}{ }_{H T}\right)$; triangle $=$ pure drying strain $\left({ }_{\varepsilon^{B}}^{B}\right)$ on set $\mathrm{B}$; circle $=$ total strain on set $\mathrm{B}\left({ }_{\varepsilon^{B}}^{B}{ }_{\text {tot }}\right)$; diamond $=$ total strain $\left(\varepsilon^{A}{ }_{t o t}\right)$ on set A.
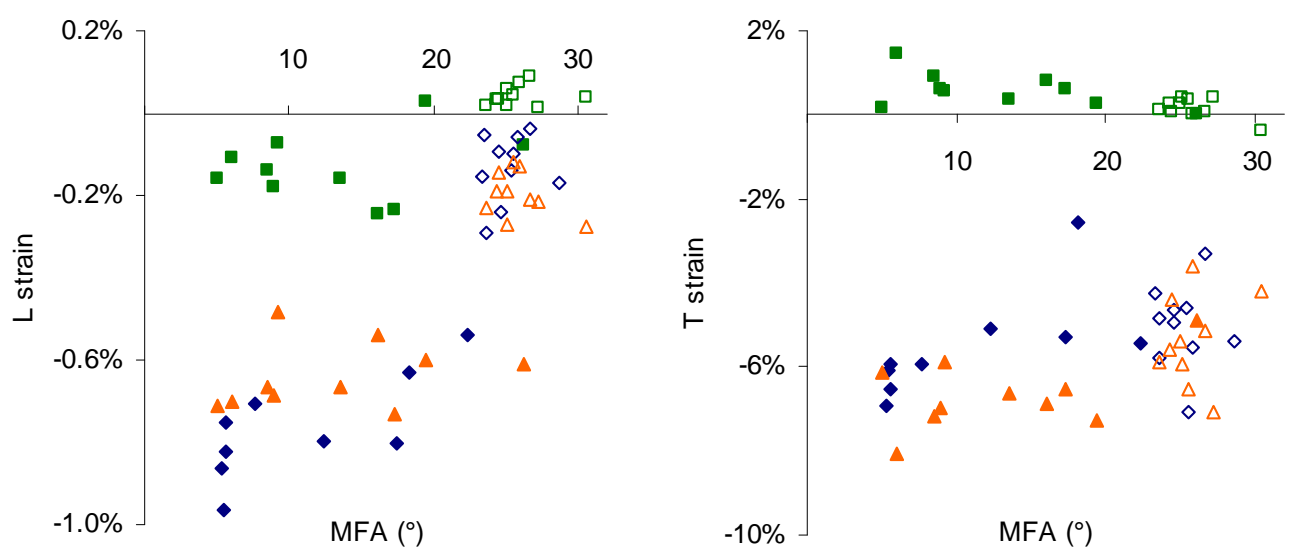

Fig. 2: Longitudinal (L) and tangential (T) strains measured on samples supposed to be normal wood (open symbols) and tension wood (filled symbols) as a function of their microfibril angle $(\mathrm{MFA})$. Square $=\mathrm{HT}$ strain on set $\mathrm{B}\left(\varepsilon_{H T}^{B}\right)$; triangle $=$ pure drying strain on set $\mathrm{B}\left(\varepsilon_{P D}^{B}\right)$; diamond $=$ total strain on set $\mathrm{A}\left(\varepsilon^{A}{ }_{t o t}\right)$. 


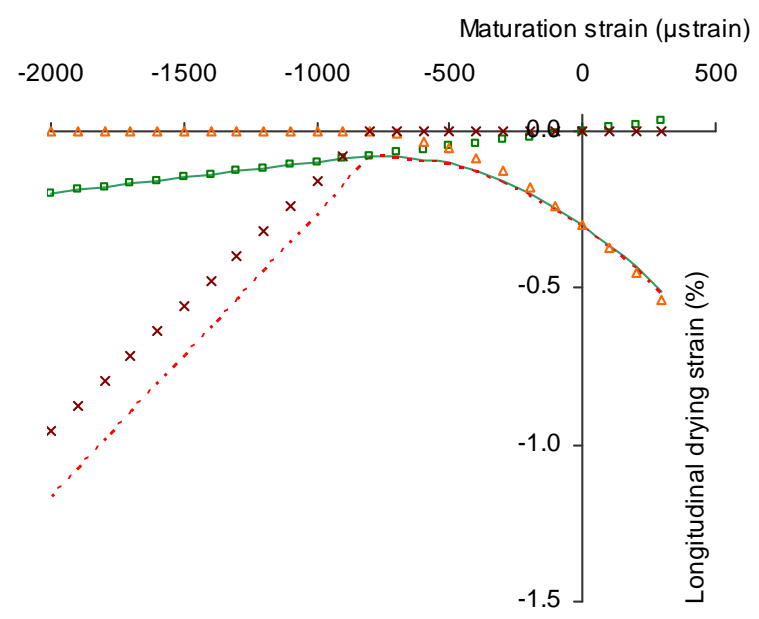

Fig. 3: Schematic model of the 3 cumulative contributions to longitudinal shrinkage as a function of the maturation strain. Green squares: strain caused by stress release; orange triangles: strain caused by water departure; crosses: strain caused by G-layer collapse. Plain line (green): resulting shrinkage on wood from species not producing G-layer; dotted line (red): resulting shrinkage on wood from species producing G-layer. 